\title{
OBITUARY
}

\section{A. SCOTT RIDOUT, M.S., F.R.C.S.}

IT is with profound regret we record the passing of Mr. Charles Archibald Scott Ridout, the distinguished Portsmouth surgeon.

He was born in 1875 at the Royal Naval Hospital, Plymouth, his father Staff-Surgeon C. L. Ridout, R.N., being on the staff there and his mother was Ada Purley, daughter of Archibald Scott of Halifax, Nova Scotia.

$\mathrm{He}$ was educated at Plymouth College and Sherborne and proceeded to St. Bartholomew's Hospital, London, qualifying in I899, obtaining the M.S., Lond., in 1903, and the F.R.C.S.Eng., in 1904, and house appointments followed at St. Bart's, North Stafford and the Royal Hospital, Portsmouth.

$\mathrm{He}$ decided to settle in Portsmouth and was successively in General Practice, General Surgeon, and Ear, Nose and Throat Specialist; holding the position of Senior Surgeon at the Royal Portsmouth Hospital and the Portsmouth and Southern Counties Eye and Ear Hospital for many years; the latter hospital was especially dear to his heart, his best work was probably done there and its destruction by bombing last year was a severe blow to him.

He was President of the Section of Laryngology of the Royal Society of Medicine, I937-39; Hon. Member of the Scottish Otological and Laryngological Society. His B.M.A. activities included service as Vice-President of the Section of Laryngology and Otology ; President, Southern Branch; Secretary, Portsmouth Division ; Chairman, Local Medical War Committee, Portsmouth, I939-4I ; and for many years he was Clinical Secretary, organizing two clinical meetings yearly.

During the war, I9I4-I8, he served as Surgical Specialist with the rank of Major, R.A.M.C., at Salonika and in Italy, and he regretted he could not serve in this.

His principal hobbies were motoring, rugger, fishing in Scotland and in later years it was his keen delight to attend the university and international matches at Twickenham and inter-hospitals at Richmond.

A painstaking, careful diagnostician and essentially a surgeon, his finest work was probably done in the theatre, where his enthusiasm infected all around him and he was never happier than when dealing with a difficult case.

Some months ago his usual vigour showed signs of lessening, until in June last an operation could no longer be postponed; he was apparently recovering when a fatal relapse occurred and he passed peacefully away.

A largely attended memorial service was held at Portsmouth Cathedral, very close to the hospital he loved so well, and after cremation at Southampton, he was buried at his beloved Sherborne. 


\section{Letter to the Editor}

His death is a severe blow to his colleagues, his many friends and a host of patients in Portsmouth and surrounding district, but his devotion to his profession, his masterly skill, his life of willing and unselfish service, his great and deep kindness of heart will be long remembered.

To his widow and children-one of his sons was at Dunkirk, another at Narvik - we extend our sincerest sympathy.

E.C.T.

\section{LETTER TO THE EDITOR}

To THE EDITOR,

The Journal of Laryngology and Otology.

DeAr Sir,-Mr. P. W. Leathart's recent paper on the subject of Mastoiditis and Infantile Mortality appears to me to be one of immense practical significance. The saving of young lives by timely mastoid operation on the lines he has suggested is most striking.

Writing from the point of view of a hospital Pathologist, the picture of findings is somewhat as follows in an untreated case :

(I) Relative infrequency of Salmonella or Dysentery pathogens in repeated stool examinations.

(2) Diminishing Hæmoglobin concentrations.

(3) Leucopenic white counts.

(4) At autopsy :

A wasted, pallid body.

Usually very slight respiratory signs.

Extremely fatty liver.

Wasted suprarenal bodies.

Intestines thin and translucent, with watery content and only rarely lymphoid inflammation.

One or both Mastoids and Middle Ears infected, with polypoid mucosa, or frank pus. Sometimes osteomyelitis of the mastoid process.

One frequently hears the adjective " terminal " applied to this infantile mastoid picture. Surely it is part of the primary, respiratory infection, or else secondary to vomiting and eustachian infection, as Mr. Leathart has pointed out. In either case, the condition is almost as sure to terminate the patients' lives as is unrelieved tibial osteomyelitis. To dismiss the condition as a relatively unimportant event in the patients' last hours seems to me to indicate an entire lack of appreciation of the earlier significance of the infection.

$$
\text { I am, Yours faithfully, }
$$

R. TAYlor ChadWick.

November I6th, I94I. 